\title{
The Effect of Subtitution Addition of Indian Copperleaf Flour and Taoge Flour Combination in Artificial Feed on Feed Utilization Efficiency and Growth of Tilapia (Oreochromis niloticus)
}

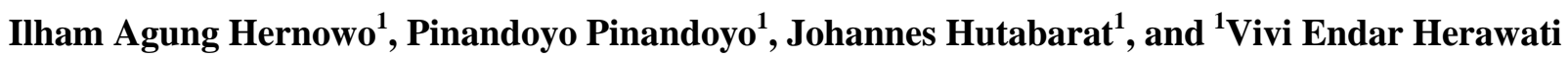 \\ ${ }^{1}$ Aquaculture Department, Fac. of Fisheries and Marine Science Diponegoro University \\ Indonesia
}

Corresponding Email : viviendar23@gmail.com

Received : 6 April 2020; Accepted: 25 June 2020

\begin{abstract}

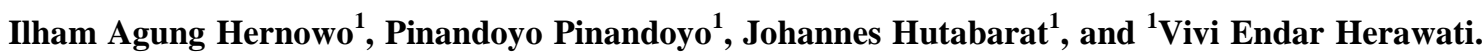
2020. The Effect of Subtitution Addition of Indian Copperleaf Flour and Taoge Flour Combination in Artificial Feed on Feed Utilization Efficiency and Growth of Tilapia (Oreochromis niloticus). Aquacultura Indonesiana, 21 (1): $32-\mathbf{- 4 1}$. Tilapia is a superior freshwater commodity in Indonesia. The problem with tilapia farmers is the high price of commercial feed because raw materials are still imported. Alternative materials are needed to reduce the cost of feed. One of the treatments is by adding local raw materials that can stimulate the growth of tilapia, namely by adding a combination of indian copperleaf flour and bean sprout flour in artificial feed that is useful to stimulate the growth of cultivated tilapia. This study aims to determine the effect and the best dose of the addition of indian copperleaf flour and taoge flour waste on artificial feed on the efficiency of feed utilization and growth of tilapia (Oreochromis niloticus) seeds. The method used is an experimental method with a Completely Randomized Design (CRD) with 4 treatments and 3 repetitions. Test fish used was tilapia with an average weight of $3.37 \pm 0.16$ grams which were kept in a bucket of $15 \mathrm{~L}$. water. The combination of earrings amaranth flour and bean sprouts flour used was in the ratio of 0\%: 0\% (A), $100 \%$ : 0\% (B), 50\%: 50\% (C) and 0\%: 100\% (D). Observation variables included the efficiency of feed utilization, growth, life pass, and water quality. The best results of this study were $50 \%$ : 50\% (C) with, RGR, EPP, FCR, PER, TKP and Survival, respectively, 3,31.60 $\pm 0,15 \% /$ day, $76.60 \pm 3,07 \%, 1.31 \pm 0.05,2.48 \pm$ $0.04 \%, 91.37 \pm 1.45$ grams and $86.67 \pm 6.67 \mathrm{a} \%$. Water quality results in maintenance in the optimal range.
\end{abstract}

Keywords: Tilapia, Feed, Growth, Indian copperleaf flour, Bean Sprouts Waste

\section{Introduction}

Tilapia (Oreochromis niloticus) has economic value and an important commodity and becoming an affordable source of animal protein. Tilapia production in Indonesia in 2015 reached 592,365 tons with an average production of 197,455 tons.Tilapia production from 2010 to 2013 experienced a fairly high increase with an average increase of $34.85 \%$. Total tilapia production was $6.83 \%$ of total aquaculture production in 2013. Comparison of total national tilapia production to total world tilapia production showed that in 2011 Indonesia ranked third as the largest producer of tilapia products with a percentage of around $20.3 \%$ of total tilapia production in the world (Salsabila et al., 2018).

The success of fish farming is greatly influenced by the availability and quality of the feed used. A feed is a source of material and energy to sustain fish survival and growth, but on the other hand, feed is the biggest component of production costs. The feed is the biggest cost for raising fish, usually around $60-75 \%$ of the total production cost (Amalia et al., 2018). Good quality food is an important factor in determining the success of fish farming. Sprouts in Indonesia are very easy to find in almost all regions in Indonesia, sprouts that are rarely used and thrown away. Indian copperleaf flour (Acalypha indica) contains saponins and tannins, flavonoids and essential oils. The content of active compounds in Indian copperleaf flour (Acalypha indica) can then be used as an antimicrobial agent (Handayani et al., 2018). Plant earring has a pharmacological effect that is as anti- inflammatory, antibiotic, astringent and laxative art (Ameilia, 2018). Indian copperleaf flour (Acalypha indica) is one of the abundant weeds. Indian copperleaf flour are still many plants that grow wild so the price is cheaper than soybean meal. Indian copperleaf 
ISSN : 2477-6939

flour usually grow on the side of the road, grass

fields that are not treated and often become a nuisance crop on agricultural land (Subkhan, 2017). 
The raw material which used is bean sprout waste which is very easy to obtain because most households often consume bean sprouts. Bean sprouts on the market are often considered useless and pollute the environment because they rot easily. In terms of nutritional content, this waste can likely be used as a feed ingredient. In addition to providing economic value and reducing environmental pollution, the utilization of market waste into new commodities can provide additional income for farmers. Bean sprouts contain $63.35 \%$

water, $7.35 \%$ ash, $1.17 \%$ fat, $13 \%-14 \%$ protein, $49.44 \%$ crude fiber and $64.65 \%$ TDN (Rahayu et al., 2010).

Based on this, the researcher wanted to know the effect and the best dose of Indian copperleaf flour flour and bean sprouts flour on artificial feed on the efficient utilization of feed, growth, and survival rate of tilapia.

\section{Materials and Methods}

The fish used in this study were tilapia seeds originating from the Freshwater Fish Seedling and Aquaculture Center in Janti, Klaten. The test fish used were tilapia seeds that would have been selected beforehand so that they were of uniform size, physical health and not deformed. Seed size used with a mean weight of $3.37 \pm 0.16$ grams. Stocking density of each container 1/ 1 liter. The tools used to support this research activity consist of a blender to smooth earrings and bean sprouts, a bucket used as a mixing container for feed ingredients, a pellet molding machine to make a feed into pellet-shaped, the jar functions as storing feed, a bucket as a container for raising fish, electric scales function as weighing fish, the ruler and millimeter block function to measure fish body length, DO meter measures $\mathrm{DO}, \mathrm{pH}$ paper, and water temperature using a thermometer, a small fish net for sampling growth and moving fish.
The method used in this study is an experimental research method with a Completely Randomized Design (CRD) consisting of 4 treatments and 3 replications. Concentration on Indian copperleaf flour flour and bean sprouts used in this study was based on concentrations from Rosyidah (2016) and Puspitasary et al. (2018), The treatments used in this study are as follows:

Treatment A: Artificial feed without a substitute for Indian copperleaf flour flour and bean sprout flour (control) Treatment B: Artificial feed with substitute Indian copperleaf flour flour 100\% and bean sprout flour 0\% Treatment C: Artificial feed substitution of earrings with spinach flour $50 \%$ and bean sprouts waste $50 \%$ Treatment D: Artificial feed with substitute $0 \%$ spinach flour earrings and $100 \%$ bean sprout waste flour.

The test feed used is artificial pellet feed with $31.67 \%$ which was partly replaced with vegetable protein content that has been replaced with Indian copperleaf flour flour and bean sprouts waste flour to replace the raw material of soybean meal according to treatment. The comparison of soybean meal flour which was replaced by Indian copperleaf flour flour and bean sprouts waste flour were treatment B (53.16\%: 46.84\%), treatment C (48.72\%: $51.28 \%)$ and treatment D (43, 34\%: 56.66\%). Comparison of protein between animal protein and vegetable protein making up the feed is $50 \%: 50 \%$, this is because tilapia is an omnivore fish where the animal protein and vegetable protein contained in the feed must be balanced. Preparation of test feed carried out includes the preparation of raw materials to be used. In the Indian copperleaf flour, the Indian copperleaf flour plant part used as flour is in the leaves, while the waste of bean sprouts flour, the material used is waste bean sprouts obtained in the market, then the preparation of feed formulations using the Ms.excel and the process of making feed. Proximate analysis is carried out aimed to determine the Results of the proximate analysis of raw materials making up the test feed shown in Table 1.

Table 1. Proximate Analysis of Raw Material Feed Ingredients Composer (wet weight) Used in Research

\begin{tabular}{|c|c|c|c|c|c|c|c|}
\hline \multirow{2}{*}{ Type } & \multirow[b]{2}{*}{ Water } & \multicolumn{2}{|r|}{ Compo } & \multicolumn{2}{|l|}{$\operatorname{nent}(\%)$} & \multirow[b]{2}{*}{ Ash } & \multirow{2}{*}{ Total $(\%)$} \\
\hline & & Protein & BETN & Fat & SK & & \\
\hline Fish Meal * & 8.65 & 45.70 & 12.27 & 6.18 & 3.26 & 23.94 & 100.00 \\
\hline $\begin{array}{l}\text { Indian copperleaf flour } \\
\text { Flour * }\end{array}$ & 7.09 & 19.64 & 30.26 & 5.07 & 21.07 & 16.87 & 100.00 \\
\hline Waste Bean Sprouts Fl & our $*$ & 11.3830 .21 & 29.03 & 2.29 & 21.46 & 5.63 & 100.00 \\
\hline Soybean Meal Flour * & 10.03 & 38.02 & 37.87 & 1.39 & 5.84 & 6.85 & 100.00 \\
\hline Bran Flour * & 11.48 & 6.36 & 30.13 & 1.59 & 34.77 & 15.67 & 100.00 \\
\hline
\end{tabular}

Source: * Laboratory of Nutrition and Feed Sciences, Faculty of Animal Husbandry and Agriculture, Diponegoro University (2019)

Note: $\mathrm{SK}=$ Coarse Fiber; BETN = Material Extracts Without Nitrogen 
After proximate analysis of each raw material, its nutritional content can be determined. Nutrient content of each ingredient from proximate analysis results and used as a reference in determining and making feed formulations to be made. After the feed formulation is made, it can proceed to the process of making the feed. The results of the test feed formulations used are presented in Table 3.

Table 3. Test Feed Formulations Used in Research.

\begin{tabular}{|c|c|c|c|c|}
\hline \multirow[t]{2}{*}{ Material Type } & \multicolumn{4}{|c|}{ Treatment (Indian copperleaf flour Flour : Waste Bean Sprout Flour) } \\
\hline & $\mathrm{A}(0: 0)$ & B (100: 0) & $\mathrm{C}(50: 50)$ & $\mathrm{D}(0: 100)$ \\
\hline Fish meal & 0 & 31.47 & 31.47 & 31.47 \\
\hline Indian copperleaf flour Flou & ur & 22 & 11 & 0 \\
\hline Waste Bean Sprout Flour & 0 & 0 & 11 & 22 \\
\hline Soybean Meal Flour & 0 & 24.97 & 20.9 & 16.83 \\
\hline Bran Flour & 0 & 7.56 & 11.63 & 15.7 \\
\hline$\overline{\text { Fish Oil }}$ & 0 & 5 & 5 & 5 \\
\hline Corn Oil & 0 & 3 & 3 & 3 \\
\hline Vit-Min mix & 0 & 5 & 5 & 5 \\
\hline $\mathrm{CMC}$ & 0 & 1 & 1 & 1 \\
\hline Total $(\mathrm{g})$ & & & & 0100100100 \\
\hline Protein $(\%)$ & 31.48 & 31.489 & 31.486 & 31.483 \\
\hline $\operatorname{BETN}(\%)$ & 28.71 & 24.476 & 24.169 & 23.862 \\
\hline Fat $(\%)$ & 7.96 & 11.851 & 11.545 & 11,240 \\
\hline En. (kcal / g) & 246,431 & 267,396 & 264,141 & 260,886 \\
\hline $\mathrm{E} / \mathrm{P}$ ratio $(\mathrm{kcal} / \mathrm{g} \mathrm{P})$ & 7,828 & 8,492 & 8,389 & 8,286 \\
\hline
\end{tabular}

Description: SK = Coarse Fiber; BETN = Extract Material Without Nitrogen; En. = Energy

The test feed that was made was carried out by the Prokmat analysis test to determine the content of the protein, carbohydrate, fiber, fat and BETN contained in the test feed to be given. The test results of proximate analyzes of feed samples used presented in Table 4.

Table 4. Feed Proximate Analysis Test Used in Research

\begin{tabular}{|c|c|c|c|c|c|c|c|}
\hline \multirow[t]{2}{*}{ Research Animal FeedTest } & \multicolumn{6}{|c|}{ Component(\%) } & \multirow{2}{*}{$\begin{array}{l}\text { Total } \\
(\%)\end{array}$} \\
\hline & Water & Protein & BETN & Fat & SK & Ash & \\
\hline A (Feed Commercial) * & 9.55 & 31.48 & 28.71 & 7.96 & 12.07 & 10.23 & 100.00 \\
\hline $\begin{array}{l}\text { B ( } 100 \% \text { of Indian copperleaf } \\
\text { flour f: } 0 \% \text { flour bean sprouts } \\
\text { waste } *\end{array}$ & 7.44 & 33.09 & 24.47 & 10.57 & 12.71 & 13.59 & 100,00 \\
\hline $\begin{array}{l}\text { C (50\% Indian copperleaf flour: } \\
50 \% \text { flour bean sprouts waste }\end{array}$ & 8,16 & 33,63 & 24,16 & 8,54 & 13,46 & 12,74 & 100,00 \\
\hline $\begin{array}{l}\text { D }(0 \% \text { Indian copperleaf flour: } \\
100 \% \text { flour bean sprouts waste }) *\end{array}$ & 8.76 & 32.69 & 23.86 & 10.44 & 10.65 & 11.74 & 100.00 \\
\hline
\end{tabular}

Source: * Laboratory of Nutrition and Feed Sciences, Faculty of Animal Husbandry and Agriculture, Diponegoro University (2019)

Note: $\mathrm{SK}=$ Coarse Fiber; BETN = Extracting Material without Nitrogen

The research used was the fish used, namely tilapia seed $(O$. niloticus $)$ with an initial weight of $3.37 \pm 0.16$ grams. The research was started by weighing the initial weight of the test fish. It was weighed using an electric scale with an accuracy of 0.01 grams. Then put in a maintenance container $20 \mathrm{~L}$. Maintenance is carried out for 42 days. Feeding with the method fix feeding rate of 5\%/day with the frequency of feeding as much as 3 times, namely at7:00, 12.00 and 17.00 (Permata et al., 2017. During the maintenance of the test fish, water quality management is carried out with the aim of which is to maintain water quality. Water quality management is by way of siphoning on a maintenance container every day. Penyiponan is done by taking the dirt at the bottom of the maintenance container and replacing the water in the maintenance container with new water. The substitution of water is carried out at $50 \%$ of the total water volume in the maintenance container to maintain optimal water quality during fish maintenance from the beginning to the end (Annisa et al, 2018). Water quality parameters 
measured include water temperature, dissolved oxygen (DO), acidity (pH). Measurement of water temperature, $\mathrm{pH}$ and dissolved oxygen (DO) is carried out every week to find out how much the dissolved oxygen content (DO) and $\mathrm{pH}$ in fish maintenance media. Sampling is done once a week to measure the weight of the test fish.

Data measured variables include, relative growth rate (RGR), feed utilization efficiency (EPP), feed conversion ratio (FCR), the protein efficiency ratio (PER), total feed consumption quality.

(TKP), survival rate (SR) and water

\section{Relative growth rate (RGR)}

Calculation of relative growth rate (RGR) is calculated by the formula according to Zonnevald et al. (1991),

Description:

$$
R G R=\frac{W_{t}-W_{0}}{W_{0} x t} \times 100 \%
$$

RGR : Relative growth rate (\% per day)

Wt : Average weight of fish at the end of maintenance (g)

Wo : Average weight of fish at the beginning of maintenance $(\mathrm{g})$

$\mathrm{t} \quad$ : Maintenance time (days)

\section{Feed utilization efficiency (EPP)}

Calculation of feed utilization efficiency (EPP) is calculated according to the formula according to Sulatsi et al. (2018),

$$
E P P=\frac{W_{t}-W_{0}}{F} \times 100 \%
$$

Description:

EPP : Efficiency of feed utilization (\%)

Wt : Weight of test fish biomass at the end of the study $(\mathrm{g})$

Wo : Weight of test fish biomass at the beginning of the study $(\mathrm{g})$

$\mathrm{F} \quad$ : Amount of feed consumed during the study (g)

\section{Feed conversion ratio (FCR)}

Formula Feed Conversion Ratio (FCR)used in the research of Dauda et al. (2018),

$$
F C R=\frac{F}{\left(W_{t}-W_{0}\right)+D}
$$

\section{Description}

FCR : Feed conversion ratio

Wt : Total weight of test animals at the end of the study $(\mathrm{g})$

Wo : Total weight of test animals at the beginning of the study $(\mathrm{g})$

F : Number feed consumed during the study (g)

D : Dead fish weight $(\mathrm{g})$

\section{Protein efficiency ratio (PER)}

Calculation of protein efficiency ratio (PER) was calculated according to the formula according to Sulasi et al. (2018),

Description:

$$
P E R=\frac{\left(W_{t}-W_{0}\right)}{P_{i}} \times 100 \%
$$

PER : Protein efficiency ratio (\%)

Wt : Weight of test fish biomass at the end of the study (g)

Wo : Weight of test fish biomass at the beginning of the study (g) Pi : Weight of feed consumed $\mathrm{x}$ protein feed levels $(\mathrm{g})$

\section{Total feed consumption (TKP)}

Calculation of total feed consumption (TKP) according to Poernomo et al. (2015), can be calculated by weighing the total amount of feed consumed by test fish every day during maintenance.

\section{Survival Rate (SR)}

According to Effendi (1997) in Setiawati et al. (2008), survival rate (SR) is the percentage of fish life that can be calculated using the following formula

$$
S R=\frac{N_{t}}{N_{0}} \times 100 \%
$$

\section{Description :}

SR : survival rate (\%)

$\mathrm{Nt} \quad$ : number of individuals at the end of the t-day (tail)

No : treatment: number of individuals at the beginning of the 0 -day treatment (tail) 


\section{Data Analysis}

The analysis includes the relative growth rate (RGR), feed utilization efficiency (EPP), feed conversion ratio (FCR), protein efficiency ratio (PER), total feed consumption (TKP) and Survival (SR) obtained righ Then analyzed using analysis of variance (ANOVA) 95\% confidence interval to see the effect of treatment. Before analyzing the variety, first, the normality test, homogeneity test, and additivity test are carried out. An additivity test was performed using Ms Excel 2010. Variance analysis data (F test) at 95\% confidence level. If the analysis obtained significantly different $(\mathrm{P}<0.05)$, then Duncan's multiple region tests were performed to determine differences between treatments. Water quality data were analyzed descriptively and compared with the feasibility of water quality in fish farming to support fish growth.

\section{Results}

The results of the substitution addtion of Indian copperleaf flour flour and bean sprout flour in artificial feed on RGR, EPP, FCR, PER, TKP and survival rate (SR) in tilapia are presented in Table 5

Table 5. Value of relative growth rate (RGR), efficiency of feed utilization (EPP), feed conversion ratio(FCR), protein efficiency ratio (PER), total feed consumption (TKP) and survival (SR) during the study.

\begin{tabular}{ccccccc}
\hline \multirow{2}{*}{$\begin{array}{c}\text { Treatment } \\
\text { of }\end{array}$} & $\begin{array}{c}\text { RGR }(\% / \\
\text { day) }\end{array}$ & EPP $(\%)$ & FCR & PER $(\%)$ & TKP $(\mathrm{g})$ & SR $(\%)$ \\
\hline A & $2.31 \pm 0.07^{\mathrm{d}}$ & $63.01 \pm 2.15^{\mathrm{c}}$ & $1.59 \pm 0,05^{\mathrm{a}}$ & $1.64 \pm 0.10^{\mathrm{c}}$ & $79.27 \pm 0.60^{\mathrm{d}}$ & $80.00 \pm 13.13^{\mathrm{a}}$ \\
B & $2.57 \pm 0.07^{\mathrm{c}}$ & $66.76 \pm 2.26^{\mathrm{c}}$ & $1.50 \pm 0.05^{\mathrm{b}}$ & $1,87 \pm 0.06^{\mathrm{a}}$ & $82.20 \pm 0.95^{\mathrm{c}}$ & $84.44 \pm 7.70^{\mathrm{a}}$ \\
C & $3.31 \pm 0.15^{\mathrm{a}}$ & $76.60 \pm 3.07^{\mathrm{a}}$ & $1.31 \pm 0.05^{\mathrm{c}}$ & $2,48 \pm 0.04^{\mathrm{d}}$ & $91.37 \pm 0.55^{\mathrm{a}}$ & $86.67 \pm 6.67^{\mathrm{a}}$ \\
D & $2.97 \pm 0.09^{\mathrm{b}}$ & $71.53 \pm 0.81^{\mathrm{b}}$ & $1.40 \pm 0.02^{\mathrm{d}}$ & $2.04 \pm 0,16^{\mathrm{b}}$ & $88.03 \pm 1.93^{\mathrm{b}}$ & $82.22 \pm 13.88^{\mathrm{a}}$ \\
\hline
\end{tabular}

Note: Values with different superscripts show significantly different results $(\mathrm{P}<0.05)$

During the research process water quality measurements were carried out including dissolved oxygen (DO), temperature and $\mathrm{pH}$. Results of water quality measurements presented in Table 6.

Table 6. Results of Measurement of Water Quality During study

\begin{tabular}{|c|c|c|c|c|c|}
\hline \multirow{2}{*}{ Parameters } & \multirow[b]{2}{*}{ of $0: 0(\mathrm{~A})$} & \multicolumn{2}{|c|}{ treatment } & & \multirow[t]{2}{*}{ Optimum range } \\
\hline & & 100: $0(\mathrm{~B})$ & $50: 50(\mathrm{C})$ & 0: $100(\mathrm{D})$ & \\
\hline $\mathrm{DO}(\mathrm{mg} / \mathrm{L})$ & $4.9-5.9$ & $5.0-6.1$ & $5.2-6.4$ & $5.1-6.3$ & $\geq 3 \mathrm{mg} / 1 *$ \\
\hline Temperature $\left({ }^{\circ} \mathrm{C}\right)$ & $27-30$ & $27-30$ & $27-30$ & $27-30$ & $25-32^{*}$ \\
\hline $\mathrm{pH}$ & $7.0-7.5$ & $7.0-7.4$ & $7.0-7.4$ & $7.0--7.4$ & $6.5-8.5^{*}$ \\
\hline
\end{tabular}

Specification: * SNI $7550:(2009)$

\section{Discussion}

Growth is a change in the size of a fish caused by changes in tissue due to cell and bone division causing substitution of weight or length of fish. According to Benedictus (2013), growth is influenced by feed both in quality and quantity. Growth in fish is influenced by internal and external factors. Internal factors include heredity, sex, and age. External factors are controllable factors that consist of water and feed quality factors. The feed is one of the important factors in aquaculture activities. In the research that has been done, the relative growth rate of fish fed with Indian copperleaf flour flour substitutes and bean sprouts with different proportions shows the results of the treatment of feed with a ratio of Indian copperleaf flour 50\% and 50\% bean sprouts $(\mathrm{C})$ significantly different $(\mathrm{P}<0,05)$ with other treatments. The highest relative growth rate was found in the treatment with 50\% Indian copperleaf flour flour substitutes and $50 \%$ bean sprouts by $3.31 \pm 0.15 \% /$ day, while the lowest yields in treatment A (treatment with 0\% Indian copperleaf flour flour substitutes and $0 \%$ bean sprouts flour) were $2.31 \pm 0.07 \% /$ day. This is presumably because there is a nutrient content that can spur the growth of tilapia in bean sprouts provided. According to Persagi (2009), vitamins found in bean sprouts are vitamin $C$, vitamin A, vitamin E, and vitamin K. Sprouts in 100 grams of wet weight have a vitamin $\mathrm{C}$ content of $15 \mathrm{mg}$, vitamin $\mathrm{E}$ as much as $9.33 \mathrm{mg}$, vitamin $\mathrm{A}$ as much as $10 \mathrm{IU}, 29 \mathrm{mg}$ of calcium, $0.8 \mathrm{mg}$ of iron, $69 \mathrm{mg}$ of phosphorus, and $92.4 \mathrm{~g}$ of water. Sprouts also contain amino acids leucine, arginine, isoleucine, valine, and lysine (Martianingsih et al., 2016). Vitamin C is needed by fish for metabolic processes in the body for growth compared to those without vitamin $\mathrm{C}$ treat 
ment (Abdan et al., 2017).

In the research that has been done, the efficiency of the use of feed-in fish fed with the substitution of Indian copperleaf flour flour and bean sprouts with different comparisons shows the results of the treatment of feed with a ratio of Indian copperleaf flour 50\% and 50\% bean sprouts $(\mathrm{C})$ significantly different $(\mathrm{P}<0,05)$ with other treatments. The highest efficiency of feed utilization was in the treatment with $50 \%$ Indian copperleaf flour flour substitutes and 50\% bean sprouts by $76.60 \pm 3.07 \%$ while the lowest yields in treatment A (treatment with $0 \%$ substitute earrings flour and $0 \%$ bean sprouts) by $63.01 \pm 2.15 \$$ According to Puspasari et al. (2015), the efficiency of feed utilization in fish farming activities with good results is more than $50 \%$ or even close to $100 \%$. Sagada et al. (2017), states that growth involves several processes and is greatly influenced by digestive physiology, as well as the absorption capacity of an organism, which can influence the basic dynamics of the utilization of incoming feed nutrition and control the extent of fish's response. The ability of fish to effectively utilize the food provided may be determined by the activity of digestive enzymes and their response to feeding that has a different composition. The efficiency of feed utilization is closely related to the digestibility of fish in the feed given. According to Paiko et al. (2010), the ability of fish to digest feed raw materials can be influenced by various factors including, the chemical nature of water, type of feed, water temperature, size, nutrient content of the feed, age of fish, feeding frequency, physical properties and chemical properties of feed, and the amount and types of digestive enzymes in the digestive tract.

In the research that has been done, the ratio of feed conversion in fish fed with Indian copperleaf flour flour substitutes and bean sprouts with different proportions shows the results of feed treatment with the ratio of Indian copperleaf flour $50 \%$ and $50 \%$ bean sprouts (C) significantly different $(\mathrm{P}<0,05)$ with other treatments. The best feed conversion ratio was found in the treatment with $50 \%$ substitution of earrings with spinach flour and $50 \%$ with bean sprouts of $1.31 \pm 0.05$. The value of the feed conversion ratio which is getting smaller will show the level of food efficiency is good. The lower the conversion value of the resulting feed shows the more efficient use of the feed. According to Arsyad et al. (2015) that the efficiency value will be inversely proportional to feed conversion and directly proportional to the body weight gain of fish, so the higher the value of feed efficiency, the lower the conversion value of feed so that fish more efficiently utilize the food consumed for growth. According to Ardita et al. (2015) that the lower FCR values indicate that the more efficient the feed and the food eaten is used well by fish for growth. Feed conversion is influenced by the absorption of feed nutrients by the digestive tract. According to Endang et al. (2013) that the value of feed efficiency is inversely proportional to feed conversion and directly proportional to the body weight gain of fish, so the higher the value of feed efficiency, the lower the conversion rate of feed so that fish more efficiently utilize the food consumed for growth. (Uliza, 2015).

In the research that has been done, the efficiency ratio of feed protein in fish fed with substituted earrings with spinach flour and bean sprouts in different proportions shows the results of feed treatment by comparison Indian copperleaf flour $50 \%$ and $50 \%$ bean sprouts (C) were significantly different $(\mathrm{P}<0.05)$ from other treatments. The highest protein efficiency ratio was found in the treatment with $50 \%$ Indian copperleaf flour flour substitute and $50 \%$ bean sprouts by $2.48 \pm 0.04 \%$, while the lowest yield in treatment A (treatment with $0 \%$ Indian copperleaf flour flour substitution and $0 \%$ bean sprouts flour) was $1.64 \pm 0.10 \%$. This is presumably due to the consumption of higher protein content, the content of feed $\mathrm{C}$ can be used efficiently to be able to produce proteins that can be optimally utilized by fish, resulting in a higher percentage of protein weight. Feed with Indian copperleaf flour flour substitute and bean sprouts flour can utilize the protein contained in the feed efficiently, thus giving a higher weight gain of tilapia compared to other test feeds. According to Adi (2015), the ratio of protein-energy is very necessary to maximize the role of protein in supporting the growth of fish seeds. It is important to be sure and non-protein to be able to determine the optimal protein level of a feed for cultured fish, to reduce protein catabolism for energy to reduce feed costs. According to Amar- 
wati (2015) that the value of protein efficiency ratio is influenced by the ability of fish to digest feed. This ability is influenced by several factors, namely the composition of the feed, where the higher the protein utilized by the body, the more efficient the protein used. Protein in the feed will be used as energy and if the excess protein is used for growth. According to Adi et al. (2015) that the protein in the feed will influence each other, when the amount of energy produced from carbohydrates and fats is not sufficient for the needs of fish life activities, then protein will be used as the main energy source. Protein is a nutrient that has a fairly expensive value, so protein is required to be the main energy in fish growth, therefore the energy in the feed must be sufficient so that protein is not used as the main energy source in the metabolic activities of the fish seed body. The energy contained in the feed will affect the metabolic activity and growth activity.

In the research that has been done, the level of consumption of feed in fish fed with substituted earrings with spinach flour and bean sprouts in different proportions shows the results of feed treatment with a ratio of Indian copperleaf flour $50 \%$ and bean sprouts $50 \%$ (C) were significantly different $(\mathrm{P}<0.05)$ from other treatments. The highest level of feed consumption was in the treatment with $50 \%$ Indian copperleaf flour flour substitutes and 50\% bean sprouts amounted to $91.37 \pm 1.45$ grams, while the lowest results in treatment $A$ (treatments with $0 \%$ substitute Indian copperleaf flour flour and $0 \%$ bean sprout flour) of $79.27 \pm$ 0.60 grams. This is presumably because of the high and low total consumption of feed is influenced by the nutritional content of the feed. Foods that are easily digested can increase the amount of feed consumed. According to Noviana et al. (2014) that the process of eating in fish starts from the level of appetite consumption, then continues with the response to stimulation and the search for sources of stimulation, determine the location, type of feed and capture of food. If the taste of the feed is following the wishes of the fish, the feed will be consumed. Conversely, if the food does not taste good, then the feed will be left or not eaten. Total feed consumption can be affected appetite of fish, the factors that influence appetite for fish are water quality by Ayu et al. (2018), water quality also influences the level of fish appetite so that it can make fish stress which results in reduced fish appetite. According to Ridwantara et al. (2019), the temperature can affect the growth and appetite of fish. Water temperature affects the appetite of fish. Low temperatures will cause the slow process of digestion of food, while warm temperatures will make the process of digestion fast. High temperatures can reduce dissolved oxygen and affect fish appetite. According to Kosim et al. (2016), increased metabolism in the fish's body can spur to consume more feed. The more food consumed, the more protein can be utilized, causing growth to increase. Nutrient content in fish feed can affect the level of consumption of tilapia.

Substitution of Indian copperleaf flour flour and bean sprouts waste flour with different comparisons, showing the results of the survival value of tilapia ( $O$. niloticus) on artificial feed substitution of earrings with spinach flour and bean sprouts with different doses the results obtained in treatments A $(80.00 \pm 13.33 \mathrm{a})$, B $(84.44 \pm 7.70 \mathrm{a}), \mathrm{C}(86.67 \pm 6.67 \mathrm{a})$, and $\mathrm{D}$ $(82.22 \pm 13.88 \mathrm{a})$. The results of various life analysis data on tilapia (O. niloticus) which were fasted with different periods showed no significant effect $(\mathrm{P}<0.05)$. The highest value in treatment $\mathrm{C}$ had a survival value of $86.67 \%$ then treatment B with a value of $84.44 \%$, treatment $\mathrm{D}$ with a value of $82.22 \%$ and the smallest was treatment A with a survival value of $82.22 \%$. Survival shows the success rate of cultivation activities. This parameter is used to measure how far the ability of tilapia larasati (O. niloticus) to survive. The results of the analysis of survival rate showed that the substitution of earrings amaranth and bean sprouts in feed did not have a significant effect ( $\mathrm{P}$ $<0.05$ ) on the survival of tilapia. One that affects the survival rate is water quality. It is suspected that feed with $\mathrm{C}$ treatment contains chemical compounds such as flavonoids, steroids, saponins, and tannins which can function as immunostimulant compounds in tilapia. Indian copperleaf flour contain active compounds in the form of secondary metabolites such as flavonoids, tannins, alkaloids, triterpenoids, and 
steroids. The content of active compounds in Indian copperleaf flour (Acalypha indica) can then be used as an antimicrobial agent (Subkhan, 2017). According to Handayani et al (2018), the compounds contained in Indian copperleaf flour are steroids, alkaloids, saponins, and flavonoids. The content of flavonoids itself acts as an antimicrobial or antibacterial, prevents blood clots, anti-inflammation, smooth metabolism, and organ function (Prabowo et al., 2017). Water quality in each treatment is almost the same. The range of each range of feasibility of tilapia. According to Annisa et al. (2018), that survival is influenced by various factors, one of which is the environmental condition of the maintenance media. Biotic factors consist of age and the ability of fish to adapt to the environment. Abiotic factors include food availability and quality of life media. The survival rate is greatly influenced by water quality especially temperature and oxygen content. Temperature is one of the factors that influence growth. According to Khoirul et al. (2017), that survival is directly affected by water quality in the environment, therefore water discharge treatment also has a direct effect on survival because with high water discharge results in higher DO, the higher DO is in the waters of fish appetite will improve and physiological and metabolic conditions run smoothly without interference. The growth rate and survival rate are affected by food availability, water quality, pests, and diseases. The availability of feed is a very important factor to consider because it will determine the growth and survival rate of fish. Appropriate feeding will be able to affect the survival rate which reduces mortality.

Water quality is an important part of fish farming because it can support growth and survival. In this study, the water quality observed included temperature, dissolved oxygen, $\mathrm{pH}$. Measurement of temperature, $\mathrm{pH}$, dissolved oxygen was observed every 3 days in the morning, afternoon and evening. The observation result of temperature during maintenance is in the range of $27-30^{\circ} \mathrm{C}$. This is confirmed by SNI, (2009), that the temperature range for the production of enlarged tilapia fish in calm water ponds is 25 -

$32{ }^{0} \mathrm{C}$. According to Ridwantara et al
(2019), that the influence of temperature on fish is in metabolic processes, such as growth and food intake, body activities, such as swimming speed and nerve stimulation. The optimal temperature will make the fish have an optimal metabolism that has a good impact on the growth and weight gain of the fish. Low temperatures will cause the rate of fish metabolism to slow and cause the appetite of fish to decrease and eventually the fish will experience slow growth. The $\mathrm{pH}$ value on the maintenance media 7 , the $\mathrm{pH}$ value is still in the normal range. According to Effendi (2003) that most aquatic biotas are sensitive to changes in $\mathrm{pH}$ and like $\mathrm{pH}$ values around 7-8.5. The $\mathrm{pH}$ value greatly affects the biochemical processes of the waters. Dissolved oxygen is one of the important variables in determining water quality. Low oxygen content in water can disrupt organ function and slow growth, and can even result in death in fish. The results of the measurement of dissolved oxygen during maintenance obtained a range of 3.82$5.40 \mathrm{mg} / \mathrm{L}$. The oxygen level is still at normal levels. According to SNI (2006) oxygen requirements for enlargement of indigo at least 3 mg / L. Zonneveld et al. (1991) that in fish farming, the availability of dissolved oxygen in water must not be less than $3 \mathrm{mg} / \mathrm{L}$. Low oxygen is generally followed by an increase in ammonia and carbon dioxide in the water which causes the nitrification process to be inhibited thus disrupting the survival of fish.

\section{References}

Abdan M., I. Dewiyanti, I. Hasri. 2017. Aplikasi Vitamin C Dalam Pakan Komersil Dengan Metode Oral Pada Benih Ikan Pedih (Tor Sp.). 2(1): 130-140

Adi M.P., Pratama, Subandiyono, Pinandoyo. 2015. Pengaruh Berbagai Rasio E/P Pakan Berkadar Protein 30\% Terhadap Efisiensi Pemanfaatan Pakan Dan Pertumbuhan Ikan Mas (Cyprinus carpio). Journal of Aquaculture Management and Technology. 4(4): 74-81

Amalia R., Amrullah, Suriati. 2018. Manajemen Pemberian Pakan Pada Pembesaran Ikan Nila (Oreochromis niloticus). Prosiding Seminar Nasional, Sinergitas Multidisiplin Ilmu Pengetahuan dan Teknologi. 1(1): 22-34

Amarwati H., Subandiyono, Pinandoyo. 2015. Pemanfaatan Tepung Daun Singkong (Manihot utilissima) Yang Difermentasi Dalam Pakan 
Buatan Terhadap Pertumbuhan Benih

Annisa D.I., Suminto, D. Harwanto. 2018. Efek Pergantian Air Dengan Persentase Berbeda Terhadap Kelulushidupan, Efisiensi Pemanfaatan Pakan Dan Pertumbuhan Benih Monosex Ikan Nila. Journal Of Aquaculture Management And Technology. 7(1): 46-54

Annisa D.I., Suminto, Dicky Harwanto.2018.Efek Pergantian Air Dengan Persentase Berbeda Terhadap Kelulushidupan, Efisiensi Pemanfaatan Pakandan Pertumbuhan Benih Monosex Ikan Nila (Oreochromis niloticus. Journal of Aquaculture Management and Technology. 7(1): 45-54

Ardita, N., A. Budiharjo dan S. L. A. Sari. 2015. Pertumbuhan dan Rasio Konversi Pakan Ikan Nila (Oreochromnis niloticus) dengan Penambahan Prebiotik. Bioteknologi. 12(1): 16-21.

Arsyad R., A. Muharam, Syamsuddin. 2015. Kajian Aplikasi Probiotik Dari Bahan Baku Lokal Terhadap Pertumbuhan Dan Tingkat Kelangsungan Hidup Benih Ikan Nila (Oreochromis niloticus). Nike: Jurnal Ilmiah Perikanan Dan Kelautan. 3(2): 51-57

Ayu D. S., S. Hastuti, Subandiyono. 2018. Pengaruh Probiotik Dalam Pakan Terhadap Performa Darah, Kelulushidupan, Dan Pertumbuhan Ikan Tawes (Puntius javanicus). Jurnal Sains Akuakultur Tropis. 2(2): 26-35

Benedictus, J. 2013. Optimalisasi Pertumbuhan Pada Pendederan Ikan Lele Sangkuriang (Clarias Sp.) Melalui Pengaturan Frekuensi Pemberian Pakan. [Skripsi]. Departemen Budidaya Perairan Fakultas Perikanan Dan Ilmu Kelautan Institut Pertanian Bogor. $61 \mathrm{hlm}$

Dauda, A.B., N. Romano, W.W. Chen, I. Natrah dan M.S. Kamarudin. 2018. Differences in Feeding Habits Influence the Growth Performance and Fedding Efficiencies of African Catfish (Clarias gariepinus) and Lemon Fin Barb Hybrid (Hypsibarbus wetmorei $\hat{\sigma} \times$ Barboides goniotus +) in a Glycerol-based Biofluc Technology System Versusu a Recirculation System. Aquaculture Engineering. 82:31 - 37.

Effendi, Hefni. 2003. Telaah Kualitas Air : Bagi Pengelolaan Sumber Daya dan Lingkungan Perairan. Penerbit: Kanisius. YogyakartaRekayasa Dan Teknologi Budidaya Perairan.1(2): 152-162

Endang J.S., Tarsim, Y.T. Adiputra dan Hudaidah S., 2013. Pengaruh Penambahan Probiotik Pada Pakan Dengan Dosis Berbeda Terhadap Pertumbuhan, Kelulushidupan,

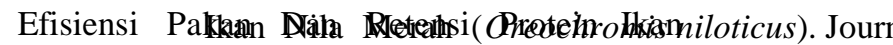
Patin (Pangasius hypophthalmus). E-Jurnal

Handayani, S., A. Kadir dan Masdian. 2018. Profil Fitokimia Dan Pemeriksaan Farmakognostik Daun Anting-Anting (Acalypha indica. L). Junral Fitofarmaka Indonesia, 5(1): 258 - 265

Khoirul M.A.,Basuki F., L. Widowati.. 2017. Performa Pertumbuhan, Kelulushidupan, Dan Produksi Biomassa Ikan Nila (Oreochromis Niloticus) dengan Debit Air Yang Berbeda Pada Sistem Budidaya Minapadi Di Dusun Kandhangan, Sleman, Yogyakarta. Jurnal Sains Akuakultur Tropis: 1 (2017)1:52-61

Kosim .M, Rachmawati D., Samidjan S..2016. Pengaruh Penambahan Enzim Fitase Dalam Pakan Buatan Terhadap Laju Pertumbuhan Relatif, Efisiensi Pemanfaatan Pakan Dan Kelulushidupan Lele Sangkuriang (Clarias Gariepinus). Journal Of Aquaculture Management And Technology. 5(2):26-34

Noviana P., Subandiyono, Pinandoyo. Pengaruh Pemberian Probiotik Dalam Pakan Buatan Terhadap Tingkat Konsumsi Pakan Dan Pertumbuhan Benih Ikan Nila (Oreochromis niloticus). Journal Of Aquaculture Management And Technology.3(4): 183-190

Nuning Martianingsih N., Wahi H.S., Darlian L. 2016. Analisis Kandungan Protein Kecambah Kacang Hijau (Phaseolus Radiatus L.) Terhadap Variasi Waktu Perkecambahan. J. Ampibi. 1(2): 38-42

Paiko M, Hashim R, Shu-Chien AC. 2010. Influence of dietary lipid/protein ratio on survival, growth, body indices and digestive lipase activity in Snakehead (Channa striatus), Bloch 1793) fry reared in recirculating water system. J. Aquaculture Nutrition

Persagi. 2009. Kamus Gizi Pelengkap Kesehatan Keluarga. Jakarta. Kompas Gramedia. 126 hlm

Poernomo, N., N.B.P. Utomo dan Z.I. Azwar. 2015. Pertumbuhan dan Kualitas Daging Ikan Patin Siam yang Diberi Kadar Protein Pakan Berbeda. Jurnal Akuakultur Indonesia, 14 (2): $104-111$.

Prabowo, A.S., B.D. Madusari Dan T.Y. Mardiana. 2017. Pengaruh Penambahan Temulawak (Curcuma xanthorriza) Pada Pakan Buatan Terhadap Pertumbuhan Ikan Bandeng (Chanos chanos). Pena Akuatika, 15(1): $40-49$.

Puspasari, T., Y. Andriani, H. Hamdani. 2015. Pemanfaatan Bungkil Kacang Tanah Dalam Pakan Ikan Terhadap Laju Pertumbuhan Ikan Nila (Oreochromis niloticus). Jurnal Perikanan Kelautan. 6(02): 91-100. 
Puspitasary D., R. I. Pujaningsih, I. Mangisah. 2018. Pengaruh Pemberian Pakan Mengandung Limbah Taoge Kacang Hijau Fermentasi Terhadap Konsumsi Ransum, Pertambahan Bobot Badan, Dan Konversi Ransum Itik Lokal. , Agromediavol. 36(1):57-66

Rahayu, S., D. Diapari., D. S. Wandito., \& W. W. Ifafah. 2010. Survei potensi ketersediaan limbah tauge sebagai pakan ternak alternatif di kotamadya Bogor. Laporan Penelitian. Fakultas Peternakan. Institut Pertanian Bogor, Bogor.

Ridwantara D., Dwi I.B., Agus A.H S., Lili W. Bangkit I. 2019.Uji Kelangsungan Hidup dan Pertumbuhan Benih Ikan Mas Mantap (Cyprinus carpio) ada Rentang Suhu Yang Berbeda. Jurnal Perikanan Dan Kelautan. 10(1): 46-54

Rosyidah, H. 2016. Standardisasi Ekstrak Etil Asetat Anting-Anting (Acalypha indica Linn.) Sebagai Herba

Sagada, G., Chen, J., Shen, B., Huang, A., Sun, L., Jiang dan Jin, C. 2017. Optimizing Protein and Lipid Levels in Particle Diet for Juvenile Northern Snakehead Fish (Channa argus). Animal Nutrition. 3 : 156-163.

Salsabila M., dan H. Suprapto. 2018. Teknik Pembesaran Ikan Nila (Oreochromis niloticus) Di Instalasi Budidaya Air Tawar Pandaan, Jawa Timur. Journal of Aquaculture and Fish Health 7(3): 1-12

Standar Nasional Indonesia (Sni) 01-6141. 1999. Produksi Benih Ikan Nila Hitam (Oreochromis niloticus Bleeker) Kelas Benih Sebar. Badan Standardisasi Nasional.

Subandiyah S., Sukarman, N. Meilisza, R. Hirnawati, dan I. Subamia. Pengaruh Perbedaan Kasein Dalam Pakan Buatan Untuk Pendederan Benih Rainbow Kurumoi (Melanotaenia parva). Ris. Akuakultur 9(2): 251-26

Subkhan, A. 2017. Uji Efektivitas Ekstrak Daun Anting (Acalypha indica) Sebagai Agen Antimikroba Terhadap Fitopatogen Xanthomonas campestris dan Colletotrichum capsici KCR2. Skripsi. UIN Sunan Kalijaga. Yogyakarta

Sulasi, S. Hastuti dan Subandiyono. 2018. Pengaruh Enzim Papain dan Probiotik Pada Pakan Buatan Terhadap Pemanfaatan Protein Pakan dan Pertumbuhan Ikan Mas (Cyprinus carpio). Jurnal Sains Akuakultur Tropis, 2(1): 1 - 10.
Uliza C., I. Dewiyanti, I. Hasri, Z. A. Muchlisin. 2017.Pertumbuhan dan Kelangsungan Hidup Benih Ikan Peres (Osteochilus vittatus) Pada Beberapa Konsentrasi Vitamin C L-Ascorbyl2-Phosphate Magnesium (L- Ap-Mg). Jurnal Ilmiah Mahasiswa Kelautan dan Perikanan Unsyiah 2(2): 229-239.

Zonneveld, N., Huisman E. A, dan Boon, J. H. 1991. Prinsip-Prinsip Budidaya Ikan. Gramedia Pustaka Utama, Jakarta, 318 hlm.

Setiawati, M., Sutajaya, R, dan Suprayudi, M. A. 2008. Pengaruh Perbedaan Kadar Protein dan Rasio Energi Protein Pakan terhadap Kinerja Pertumbuhan Fingerling Ikan Mas (Cyprinus carpio). J. Akuakultur Indonesia, 7(2): 171-178 